\title{
Keunggulan Kurikulum Holistik Integratif dalam Pembentukan Kepribadian Anak di PPA Cluster Medan - Pancur Batu
}

Tiur Imeldawati ${ }^{* 1}$, Yefta Nainggolan, Warseto Freddy Sihombing ${ }^{3}$

Institut Agama Kristen Negeri Tarutung

*imeltamsar@gmail.com

\begin{abstract}
The holistic curriculum is a character-based curriculum that encourages students to find their potential, identity, and abilities until finally forming the personality of students as God wants. The purpose of this study is to see the advantages of a holistic curriculum in the formation of children's personality which is applied in PPA Cluster Medan-Pancur Batu. The research method used is a quantitative method, by taking samples from children who are members of several PPAs who are members of the Medan Pancur Batu Cluster. The findings of this study are that the advantages of the holistic integrative curriculum that are applied include: being able to encourage the exploration of children's intellectual abilities through the implementation of the curriculum, in addition to intellectual abilities, this curriculum also encourages children's socioemotional abilities and skills related to physical abilities, other advantages. is that children are given the freedom to explore and find their superiority through screening their talents or interests, and in the end children can become individuals who can actualize themselves who are spiritually educated in the guidance of the truth of God's word.
\end{abstract}

Keywords: superior, curriculum, integrated holistic, personality

Abstrak: Kurikulum holistic nerupakan kurikulum berbasis karakter yang mendorong peserta didik menemukan potensi diri, jati diri, kemampuan yang dimiliki sampai pada akhirnya membentuk kepribadian peserta didik sebagaimana yang Tuhan kehendaki. Tujuan penelitian ini adalah untuk melihat keunggulan kurikulum holistic dalam pembentukan kepribadian anak yang diterapkan di PPA Cluster Medan-Pancur Batu. Metode penelitian yang digunakan adalah metode kuantitatif, dengan mengambil sampel dari anak-anak yang merupakan anggota dari beberapa PPA yang tergabung dalam Cluster Medan Pancur Batu. Adapun temuan penelitiian ini bahwa keunggulan kurikulum holistic integrative yang diterapkan antara lain adalah: mampu mendorong eksploarasi kemampuan intelektual anak melalui implementasi kurikulum yang dilakukan, selain kemampuan intelektual, kurikulum ini juga mendorong kemampuan sosio-emosional anak dan kemampuan skill yang berkaitan dengan fisik, keunggulan lainnya adalah anak-anak diberikan kebebasan untuk menggali dan menemukan keunggulan diri melalui penjaringan bakat atau pun minat mereka, dan pada akhirnya anak-anak bias menjadi pribadi-pribadi yang dapat mengaktualisasikan diri mereka yang dididik secara spiritual di dalam tuntunan kebenaran firman Allah.

Kata kunci: unggul, kurikulum, holistik integratif, kepribadian

\begin{tabular}{llll}
\hline Article History : & Received: 28-08-2021 & Revised: 07-12-2021 & Accepted: 30-12-2021
\end{tabular}




\section{Pendahuluan}

Dalam penelitian ini yang menjadi pertanyaan penelitian yang melatar belakangi penelitian adalah adalah: Pertama, Mengapa kurikulum Holistik Integratif tetap perlu diimplementasikan? Kedua, Apakah yang menjadi keunggulan Kurikulum Holistik Integratif yang telah digunakan selama ini?

Adapun tujuan dari penulisan ini adalah: Pertama, untuk menjelaskan bahwa muatan kurikulum Holistik Integrtif tidaklah seberat seperti yang dibayangkan atau dipikirkan dan terbukti tetap relevan diimplementasikan hingga kini. Kedua, untuk membuktikan Bahwa kurikulum Holistik Integratif memiliki keunggulan dalam upaya pembentukan kepribadian anak di PPA Cluster Medan Pancur Batu.

Sebagaimana disebutkan oleh Elisabeth Sarinastitin bahwa pendidikan integratif dan terpadu merupakan pendidikan yang menyatakan keseluruhan yang menjadi dasar untuk pembentukan karakter. Pembentukan karakter integrative dan terpadu sangat ditentukan oleh keterlibatan banyak pihak. ${ }^{1}$ Pembentukan karakter memang merupakan hal yang sangat penting untuk diperhatikan oleh para praktisi pendidikan saat ini. Banyak pihak sudah semestinya bersinergi untuk mewujudkan generasi berkarakter di era milenial ini.

Pendidikan karakter merupakan hal yang penting untuk dicermati, ditindaklanjuti secara serius dan dikelola secara bertanggung jawab. Ketika semua pihak bersinergi tentunya akan memaksimalkan pencapaian. Generasi muda yang berkarakter akan mengantarkan bangsa ini ke masa depan yang lebih baik. Sebab negeri ini tidak kekurangan orang-orang yang pintar tetapi membutuhkan orang-orang berkarakter baik untuk membangun negeri dan memajukan bangsa ini. Dan semuanya ini haruslah dimulai sejak dini, sejak generasi bangsa ini masih kecil, dan masih lebih mudah dibentuk.

Dalam penelitian berbeda, Pramudyani menuliskan bahwa kurikulum ini penting bagi penyelenggaraan PAUD di Yogyakarta. Penelitian ini bertujuan untuk memperoleh informasi tentang kurikulum holistik integratif yang dikembangkan pada PAUD. Kurikulum holistik integratif yang diterapkan di PAUD lebih bermakna apabila lingkungan sekitar anak yang dapat dijadikan sebagai dasar pengembangan. ${ }^{2}$

${ }^{1}$ Elisabeth Sarinastitin, "Pendidikan Holistik Integratif dan Terpadu Untuk Pembentukan Karakter Anak Usia Dini," Unnes.ac.id 2, no. 2 (2019).

2 Avanti Vera Rusty Pramudyani, "Kurikulum Holistic Integrative Berbasis Permainan Tradisional Pada PAUD di Yogyakarta," Jurnal Penelitian Ilmu Pendidikan 10, no. 2 (2017). 
Yayasan Compassion International yang menggagas Kurikulum Integratif ini memang sudah cukup lama melakukan pelayanan di Indonesia. Lamanya usia pelayanan dan kerjasama yang dilakukan dengan gereja-gereja Indonesia memberi kontribusi dalam membangun generasi Kristen di negeri ini. Pendidikan Agama Kristen memang perlu mengalami terobosan untuk mengalami peningkatan dalam kulaitas pengimplementasiannya, dan ini jugalah yang dilakukan oleh Yayasan Compassion bekerja sama dengan gereja dalam Programa PPA yang dilakukan. Kurikulum Holistik tetap digunakan, dan disesuaikan dengan konteks kekinian melalui pengembangan program pada masing-masing PPA sebagai wujud nyata pengimplementasiannya. Pembuatan site plan, dengan mengacu pada World View, pemilihan programa-program pendukung terlaksananya kurikulum holistic oleh masing-masing PPA dan evaluasi yang dilakukan secara berkala, untuk pengembangan dari masing-masing PPA sesuai konteks kebutuhan merupakan hal yang membuktikan bahwa Compassion masih tetap relevan hingga kini. Sebagaimana disebutkan oleh MacCullough bahwa tujuan Pendidikan adalah meningkatkan perkembangan manusia, yaitu menghidupi peran sebagai ciptaan Allah yang segambar dengan-Nya. Koherensi dan integrasi adalah penjelas (descriptor) kurikulum antara lain teori kurikulum, desain dan pengembangan kurikulum. ${ }^{3}$

Narwono menjelaskan bahwa kurikulum holistik integratif adalah kurikulum yang memiliki tujuan berupa membawa perubahan pada anak-anak, perubahan yang diharpkan terjadi adalah perubahan pengetahuan, tingkah laku, karakter, kebiasaan dan sebagainya. ${ }^{4}$ Kurikulum Holistik integratif mengandung aspek fisik, spiritual, intelektual, sosio-emosional. Dalam pelaksanaannya, tujuan dari implementasi kurikulum ini adalah membantu dalam mengembangkan potensi setiap individu di dalam pembelajaran agar lebih menyenangkan, menggairahkan, demokratis, dan lebih humanis melalui pengalaman berinteraksi dengan lingkungannya. ${ }^{5}$

Holistik dimengerti sebagai sebuah cara pandang terhadap sesuatu yang dilakukan dimana terdapat konsep pengakuan bahwa hal keseluruhan adalah sebuah kesatuan yang lebih penting dari bagian-bagian yang membetuknya ${ }^{6}$ sebagaimana yang diungkap oleh beberapa ahli bahwa kata "holistic" berasal dari Bahasa Inggris yang mememiliki

3 Martha E. MacCullough, Mengembangkan Filosofi Pendidikan Berdasarkan Wawasan Dunia Kristiani (Malang: Gandum Mas, 2019), 156.

4 Abdiel E.Nawono, Buku Panduan Untuk Mentor Kurikulum Holistik Integratif, (Yayasan Compassion Indonesia:Bandung, 2018), 6.

5 Dewi Iswari Puspitawati, Buku Panduan Untuk Mentor Kurikulum Holistik Integratif kelompok Umur 15-18, (Bandung: Yayasan Compassion Indonesia, 2016), 6

6 Kurikulum, Compasion: Buku Panduan Pembimbing Kurikulum Holistik Integratif. Compassion Indonesia. 2019. 
arti penekanan terhadap betapa pentingnya keseluruhan keterkaitan bagian-bagian tersebut.

Proses pembelajaran dengan menggunakan kurikulum holistik sering juga disebut sebagai pelayanan holistik. Pembelajaran ini menyangkut pengetahuan anak akan moral yang baik dan mana yang salah dengan berpusat pada pembentukan kepribadian anak dengan mengoptimalkan potensi yang dimiliki oleh anak. Pelayanan holistik merupakan pelayanan yang juga seharusnya diterapkan dalam pelayanan kekristenan, khususnya oleh gereja dan umat Allah, untuk memampukan anak-anak miskin dan keluarga miskin keluar dari kemiskinan mereka agar sama seperti yang dikehendaki Tuhan. ${ }^{7}$ Jika kita ingin memberi campur tangan secara holistik maka secara definisi, campur tangan tersebut haruslah mencakup kebutuhan-kebutuhan rohani maupun fisik. Artinya dalam segala aspek kehidupan, pelayanan holistik ini adalah pelayanan yang seharusnya dilakukan oleh orang percaya.

Holistik integratif sangat sering dikaitkan dalam bidang pendidikan. Yang dimaksud dengan pendidikan holistik integratif berkaitan dengan filsafat pendidikan yang bersumber dari pemikiran bahwa pada dasarnya setiap individu menemukan identitas dirinya, tujuan dan makna hidupnya melalui hubungan yang terjalin dengan masyarakat, nilai-nilai spiritual yang dimiliki dan lingkungan alam sekitar. Holistik menunjuk kepada ruang lingkup dari pengembangan anak secara menyeluruh. Pendidikan holistik integratif ini dilakukan bertujuan dalam membantu mengembangkan semua potensi yang dimiliki setiap individu (khususnya anak) dengan suasana pembelajaran yang berbeda dan jauh lebih menyenangkan, bersifat demokratis serta humanis. Sebagaimana dituliskan oleh Oktaviani, bahwa anak merupakan individu yang utuh maka dalam pengembangannya diperlukan pelayanan secara holistic guna memenuhi kebutuhannya. ${ }^{8}$

Pelayanan secara holistik kepada anak yang diberikan kepada setiap anak menolong mereka untuk mengembangkan diri mereka, menggali potensi yang dimiliki anak sejak dini dan mempersiapkan masa depan anak-anak, untuk sebuah masa depan cerah dan gemilang. Gereja sebagai mitra dari Compassion mengambil peran mereka dalam hal ini dan akan terus berkarya selama masih ada peluang dan kesempatan untuk melakukan hal tersebut.

7 Dan Bwester, Anak, Gereja Dan Misi-Buku Panduan Pembimbing Kurikulum Holistik Integratif (Bandung: Compassion International, 2016).

8 Dimyati Oktaviani, Dewi Ayu, "Penerapan PAUD Holistik Integratif Pada Masa Pandemi Covid 19," Obsesi: Jurnal Pendidikan Anak USia Dini 3, no. 2 (2021). 


\section{Penyusunan Kurikulum Holistik Integratif}

Penyusunan kurikulum Holistik Integratif ini dilakukan dengan menentukan tema-tema pembelajaran yang sesuai dengan kebutuhan setiap peserta didik. Penulis telah menjelaskan di atas bahwa kurikulum ini disusun pertiga bulan dalam satu materi yang harus dituntaskan habis oleh setiap penyelenggara pendidikan yang ikut bekerjasama dengan yayasan Compassion ini.

Penyususnan semacam ini bertujuan untuk melihat kebutuhan anak kedepanya yang akan disesuaikan dengan kurikulum berikutnya. Jadi sangat efektif dan efisien penyusunanya karena selalu melihat kepada kebutuhan dari setiap individu yang diajarkan. Penyususnan kurikulum ini juga sangatlah variatif, dimana kurikulum ini tidak hanya menitik beratkan kepada penyampaian teori tetapi menyeimbangkan dengan pengaplikasian secara nyata dalam pembelajaran dan kehidupan sehari-hari dari peserta didik.

Penyusunan kurikulum holistik integratif ini disusun berdasarkan penentuan tema besar yang harus dicapai dalam kurikulum ini dan harus dikerjakan. Selain itu juga penentuan garis besar materi pembelajaran yang dikembangkan melalui penentuan garis bersar yang sudah di tetapkan. Setelah adanya penentuan tema-tema besar dan garis besar, maka dilanjutkan dengan pembahasan secara terperinci.

Dalam pembahasan ini yang perlu diperhatikan adalah menentukan tujuan dari materi yang disampaikan, goal apa yang harus dicapai dan harus tercapai dari materi yang disampaikan. Demikian juga memperhatikan Aset. Nawono mengatakan dari 40 aset yang telah ditetapkan, harus ditentukan aset mana yang harus dicapai untuk pembentukan kepribadian anak. Memperhatikan juga ketentuan-ketentuan yang harus dipenuhi, baik itu dari jumlah peserta didik, waktu yang diperlukan, perlengkapan dalam penyampaian materi, tempat yang sesuai dengan materi, dan penyampaian atau strategi dalam penyajian dan sampai pada akhirnya yang tidak boleh dilupakan adalah selalu mengadakan evaluasi. ${ }^{9}$

Kesinambungan merupakan hal yang perlu untuk diperhatikan. Semuanya seperti sebuah paket yang tidak bisa dipisahkan. Dalam penyusunan kurikulum, dilanjutkan dengan pengorganisasiannya dan pelaksanaan yang baik. Evaluasi merupakan kelanjutan dari ketiga hal di atas, dan perlu dilakukan dengan baik demi terwujudnya peningkatan kualitas pembelajaran.

${ }_{9}^{9}$ Abdiel E. Nawono, Buku Panduan Untuk Mentor Kurikulum Holistik Integratif. (Bandung: Yayasan Compassion, 2018). 
Kurikulum holistik integrtatif yang telah disusun oleh Compassion diterapkan oleh masing-masing mitra yakni di masing-masing pusat pengembangan anak. Dan dari implementasi tersebut secara berkala dilakukan evaluasi dan monitoring, dan pada akhirnya hasil yang diharapkan adalah anak-anak didik yang berkarakter, handal dalam berbagai bidang kecerdasan dan dapat mengembangkan diri dengan baik untuk masa depan yang gemilang. Pencapaian yang baik tentunya membutuhkan komitmen yang besar, kerjasama yang baik dan peningkatan kualitas sumber daya manusia sebagai pelaksana dalam pembelajaran.

\section{Strategi Pelaksanaan Kurikulum Holistik Integratif}

Penyusunan kurikulum yang sangat variatif demikian juga strategi pelaksanaanya yang sangat bervariasi, membuat pembelajaran itu disampaikan senyaman mungkin dan sejelas mungkin dan peserta didik yang mengikutinya tidak akan merasa kewalahan atau merasakan kebosanan yang berarti. Dibutuhkan kepiawaian dalam melakukan hal ini.

Penyusunan kurikulum yang baik tidaklah cukup tanpa pelaksanaan yang maksimal. Ketika kurikulum holistik sudah disusun dibutuhkan komitmen yang besar untuk melaksanakan hal-hal yang telah disusun tersebut. Keseimbangan dalam perencanaan dan pelaksanaan merupakan hal yang sama pentingnya dalam mewujudkan goal yang ingin dicapai.

Ketika penyusunan kurikulum kurikulum telah dilakukan, hal tersebut masih setengah dari perjalanan perjuangan pembentukan kepribadian anak. Dibutuhkan pelaksanaan yang sesuai dengan apa yang telah disusun. Strategi yang tepat dibutuhkan dalam pelaksanaan kurikulum holistik ini. Para tutor dan mentor juga merupakan orang kunci yang memegang peran yang penting dalam keberhasilan implementasi kurikulum holistik. Sebuah kurikulum yang baik perlu diimbangi dengan sumber daya manusia yang unggul juga untuk mampu mengimplementasikan kurikulum yang baik tersebut.

Membentuk manusia secara utuh (holistik) yang berkarakter, yaitu mengembangkan aspek fisik, emosi, sosial, kreativitas, spiritual dan intelektual siswa secara optimal. Selain itu untuk membentuk manusia yang lifelong learners (pembelajar sejati) Rahmiatkin menjelaskan dengan menerapkan beberapa strategi, seperti:

Pertama, Menerapkan metode belajar yang melibatkan partisipasi aktif murid, yaitu metode yang dapat meningkatkan motivasi murid karena seluruh dimensi manusia terlibat secara aktif dengan diberikan materi pelajaran yang konkrit, bermakna, serta relevan dalam konteks kehidupannya (student active learning, contextual learning, inquirybased learning, integrated learning). Kedua, Menciptakan lingkungan belajar yang kondusif 
(conducive learning community) sehingga anak dapat belajar dengan efektif di dalam suasana yang memberikan rasa aman, penghargaan, tanpa ancaman, dan memberikan semangat. Ketiga, Memberikan pendidikan karakter secara eksplisit, sistematis, dan berkesinambungan dengan melibatkan aspek knowing the good, oving the good, and acting the good. Keempat, Metode pengajaran yang memperhatikan keunikan masing-masing anak, yaitu menerapkan kurikulum yang melibatkan juga 9 aspek kecerdasan manusia. Kelima, Seluruh pendekatan di atas menerapkan prinsip-prinsip Developmentally Appropriate Practices. ${ }^{10}$

Kesadaran bahwa setiap anak adalah cerdas perlu untuk ditanamkan pada masingmasing tutor dan mentor sebagai pelaksana kurikulum yang diterapkan di PPA ini. Dalam pemilihan metode belajar para tutor dan mentor perlu untuk memotivasi anak menjadi orang-orang yang aktif dan terlibat dalam interaksi belajar mengajar dengan baik. Mereka bukan hanya duduk untuk mendengar saja, melainkan bisa terlibat secara aktif dalam pembelajaran yang dilakukan dan dalam semua program yang diselenggarakan oleh PPA. Anak juga memerlukan rasa nyaman berada di kelas mereka, tidak merasa terancam dan dapat menggali potensi diri yang mereka miliki. Ketika para tutor memberikan materi ajar, seharusnya tetap menyisipkan pendidikan karakter secara nyata, dimana dari setiap materi ajar, ada karakter khusus yang ingin ditanamkan kepada anak misalnya menjadi anak yang jujur, taat, anak yang bertanggung jawab dan berbagai karakter lainnya sesuai materi ajar.

Keunikan setiap anak juga merupakan hal yang penting untuk diperhatikan oleh para tutor dan mentor. Setiap anak memiliki kecerdasan masing-masing dan tentunya menonjol dalam bidang yang berbeda-beda. Sebagai pendidik tentunya tidak boleh memaksakan atau menuntut anak-anak memiliki kemampuan yang sama untuk setiap bidang. Sebab anak memiliki kecerdasan yang majemuk, dan itulah yang perlu untuk dieksplor yakni di bidang apa si anak ini memiliki keunggulan dan potensi yang besar untuk dikembangkan.

Para mentor memiliki tanggung jawab memberikan pendampingan secara khusus pada anak, bukan hanya memberikan materi ajar, melainkan mendampingi mereka sebagai seorang mentor untuk pembentukan kepribadian anak-anak yang menjadi tanggung jawab mereka. Biasanya mentor diklasifikasi untuk usia anak misalnya mentor usia 3-6 tahun, mentor usia 6-9 tahun, mentor usia 9-12 tahun, mentor usia 12-15 tahun dan mentor usia 15-18 tahun. Para mentor ini memiliki tanggung jawab yang besar terhadap perkembangan masing-masing anak.

\footnotetext{
${ }^{10}$ Rahmiatkin, Pendidikan-holistik-berbasis-karakter.http:// html, diakses 17 april 2017.
} 
Strategi pelaksanaan pembelajaran merupakan hal yang sangat penting dalam berjalanya proses pembelajaran dengan baik. Jika metode yang digunakan sesuai dengan bahan yang disampaikan maka proses pembelajaran akan berjalan dengan baik dan demikian sebaliknya. Bukan hanya itu pelaksanaan pembelajaran juga harus diperhatikan melalui lingkungan yang nyaman bukan hanya materi pembelajaran yang menarik tetapi juga ditunjang dengan suasana.

\section{Metode Penelitian}

Metode penelitian yang dipakai adalah metode kuantitatif, ada pun prosedur yang dilakukan adalah observasi awal dengan melakukan wawancara terhadap tutor dan mentor, untuk mengetahui masalah-masasalah yang dihadapi sehingga dapat merumuskan penelitian, mencari sumber-sumber atau literatur yang penting untuk mendukung pelaksanaan penelitian dan yang digunakan sebagai literatur utama adalah buku Panduan Kurikulum Holistik Integratif yang diterbitkan oleh Yayasan Compassion. Langkah berikutnya adalah penelitian lapangan dengan menyebarkan angket kepada sampel penelitian yang diambil. Cluster Medan-Pancur Batu terdiri atas beberapa PPA. Dalam Analisa data, digunakan program aplikasi SPSS (Statistical Package for Social Science) untuk mempermudah pengolahan data tersebut. Nawono menjabarkan panduan kurikulum holistik integratif adalah sebagai berikut:

Panduan kurikulum holistik integratif memiliki 40 aset bagi perkembangan pembentukan kepribadian berdasarkan urutan nomor 'Dukungan: dukungan keluarga, komunitas keluarga positif, relasi dengan orang dewasa lainya, lingkungan yang peduli, keterlibatan orang tua disekolah. Pemberdayaan: komunitas menghargai anak muda, anak muda sebagai sumber daya, melayani orang lain, kenyaman. Batasan dan harapan: batasan keluarga, batasan sekolah, batasan lingkungan, teladan dari orang dewasa, pengaruh teman sebaya yang positif, harapan yang tinggi. Penggunaan waktu yang membangun: kegiatan yang kreatif, program bagi anak muda, komunitas agama, waktu dirumah. Komitmen untuk belajar: motivasi untuk pencapaian, keterlibatan di sekolah, pekerjaan rumah, kedekatan dengan sekolah, membaca untuk kesenangan. Nilai-nilai positif : kepedulian, kesetaran dan keadilan sosial, integritas, kejujuran, tanggung jawab, menahan diri. Kompetensi sosial : perencanaan dan pengambilan keputusan, kompetensi interpersonal, kompetensi budaya, kecakapan untuk bertahan, pemecahan konflik dengan damai. Identitas positif :kekuatan pribadi, harga diri, kesadaran akan tujuan, pandangan positif akan masa depan pribadi. ${ }^{11}$

11 Abdiel E.Nawono, Buku Panduan Untuk Mentor Kurikulum Holistik Integratif (Yayasan Compassion Indonesia:Bandung, 2018)13-14. 
Acuan yang dipakai oleh penulis dalam merancang penelitian ini adalah apa yang dipaparkan oleh Creswell perihal penelitian kuantitatif. ${ }^{12}$ Pembentukan kepribadian dipengaruhi oleh banyak pihak dan banyak hal dalam hidup seorang anak. Pelayanan yang baik terhadap anak, penanaman nilai-nilai hidup, penerimaan diri dan pembentukan sejak dini dalam keluarga, dan pendidikan yang dikecap di lingkungan masayarakat juga tidak bisa diabaikan dalam hal ini. Keluarga, sekolah, gereja dan masyarakat secara umum memiliki peran masing-masing dalam mewujudkan generasi berkarakter.

\section{Hasil dan Pembahasan}

Kurikulum Holistik Integratif mengandung aspek fisik, spiritual, intelektual, socialemosional. Tujuan dari kurikulum holistic integrative sendiri membantu dalam mengembangkan potensi setiap individu di dalam suasana pembelajaran agar lebih menyenangkan serta menggairahkan, demokratis dan lebih humanis melalui pengalaman dalam berinteraksi dengan lingkungannya. Dengan demikian, diharapkan peserta didik dapat menjadi dirinya sendiri. Lebih spesifiknya lagi bahwa kurikulum Holistik Integratif ini mempengaruhi perkembangan kepribadian peserta didik. Kurikulum ini menyajikan Pendidikan yang berpusat pada pengembangan potensi diri setiap peserta didik.

Kurikulum ini diterapkan oleh Pusat Pengembangan Anak (PPA) di seluruh dunia, hanya saja penelitian ini dilakukan dalam lingkup Cluster Medan-Pancur Batu. Proses pembelajaran dalam Pusat Pengembangan Anak dirancang dengan baik demi tercapainya tujuan dari pendidikan tersebut dengan menggunakan kurikulum Holistik. Demikian juga dengan kegiatan-kegiatan yang dilakukan cukup bervariasi. Kegiatan yang dilakukan adalah kegiatan pembukaan, kegiatan inti, tanggapan dan aplikasi serta kegiatan penutup. Jadi semuanya kegiatan terprogram dan tersusun dengan baik. ${ }^{13}$ Proses pembelajaran memperoleh hasil merupakan ukuran dan tanda-tanda yang kelihatan bahwa tujuan dari pembelajaran tercapai.

\section{Keunggulan Kurikulum Holistik Integratif}

Dalam riset ini, sampel penelitian adalah anak laki-laki dan anak perempuan dengan keterangan sebagai berikut:

12 John W Creswell, Research Design: Pendekatan Metode Kualitatif, Kuantitatif Dan Campuran (Yogyakarta: Pustaka Pelajar, 2019).

13 Tim Kurikulum, Compasion, Buku Panduan Pembimbing KurikulumHolistik Integratif. 
Dari pengolahan data yang dilakukan, Frekuensi Responden Berdasarkan Jenis Kelamin

\begin{tabular}{|l|l|l|l|l|l|}
\hline & & Frequency & Percent & $\begin{array}{l}\text { Valid } \\
\text { Percent }\end{array}$ & Cumulative Percent \\
\hline Valid & Laki-laki & 28 & 46.7 & 46.7 & 46.7 \\
& Perempuan & 32 & 53.3 & 53.3 & 100.0 \\
& Total & 60 & 100.0 & 100.0 & \\
\hline
\end{tabular}

Berdasarkan hasil pengolahan data dengan uji frekuensi pada tabel 4 di atas, diperoleh hasil analisa untuk karakteristik pertama responden yakni "Jenis Kelamin" bahwa responden jenis kelamin laki-laki sebanyak 28 orang $(46,7 \%)$ dan responden jenis kelamin perempuan sebanyak 32 orang $(53,3 \%)$.

Frekuensi Berdasarkan Usia

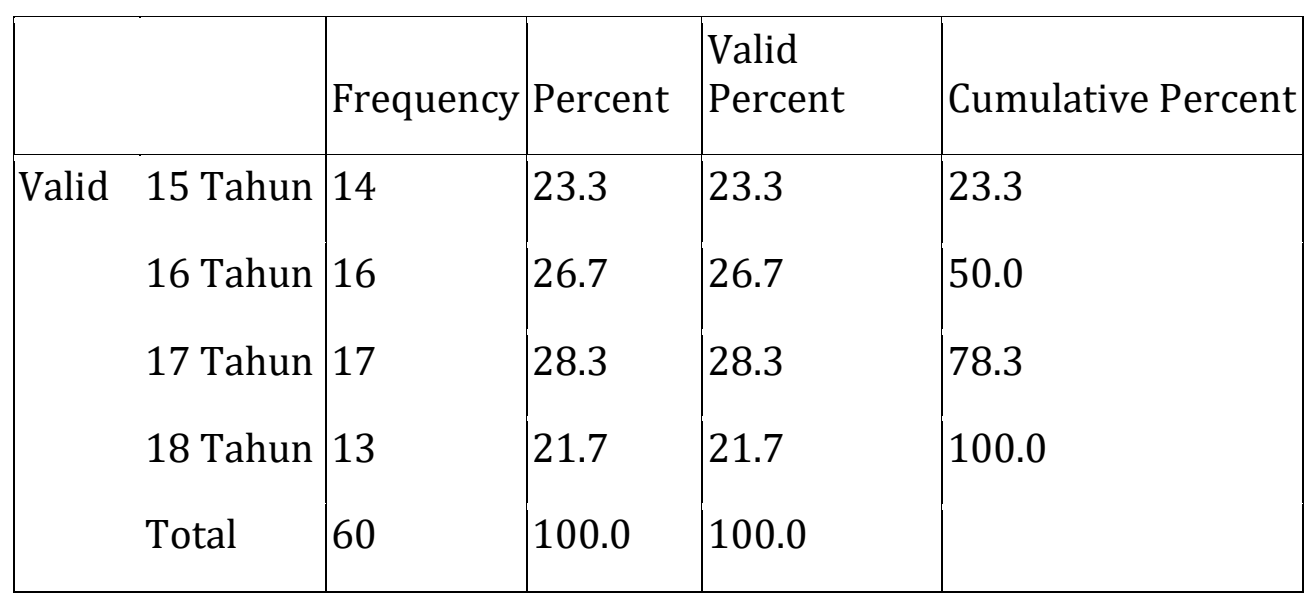

Berdasarkan hasil pengolahan data dengan uji frekuensi pada tabel 5, diperoleh hasil analisa untuk karakteristik kedua responden yakni "usia" bahwa responden berusia 15 tahun sebanyak 14 orang (23,3\%), responden berusia 16 tahun sebanyak 16 orang $(26,7 \%)$, responden berusia 17 tahun sebanyak 17 orang $(28,3 \%)$ dan responden berusia 18 tahun sebanyak 13 orang $(21,7 \%)$.

Dari penelitian yang dilakukan terhadap responden ditemukan beberapa keunggulan Kurikulum Holistik Integratif yang diterapkan di PPA Cluster Medan Pancur Batu antara lain: 
Pertama: membentuk intelektual yang lebih baik, hal ini dibuktikan dari semakin tingginya semangat belajar dan keberhasilan peserta didik $(86,7 \%)$, semakin mandiri dalam hidupnya $(87,7 \%)$. Kedua, membentuk sosio-emosional yang lebih baik, hal ini dibuktikan dengan terpupuknya rasa percaya diri (80\%), lebih terbuka terhadap orang lain $(81,7 \%)$, bisa menerima orang lain $(86 \%)$, dapat bekerja sama $(88.3 \%)$, dapat menguasai emosi (85\%) menghargai orang tua $(88,3 \%)$.

Ketiga, membentuk spiritual yang lebih baik, hal ini dibuktikan dengan adanya hubungan yang baik dengan Tuhan (93,3\%), semakin rajinnya mereka mengikuti kegiatan gereja $(83,3 \%)$ dan peserta didik mengetahui tujuan hidup mereka $(93,4 \%)$. Keempat, membentuk fisik yang lebih sehat, hal ini dibuktikan dengan keseimbangan menu yang diberikan dalam kegiatan PPA dan kondisi kesehatan, berat badan dan tinggi badan yang diperiksa secara berkala, sekaligus juga dengan pemberian vitamin kepada anak-anak (86\%). Kelima, membentuk potensi diri sesuai bakat $(81,6 \%)$, dan memiliki perilaku yang baik $(91,7)$

\section{Kesimpulan}

Dari penelitian yang telah dilakukan disimpulkan bahwa: Pertama, Kurikulum Holistik Integratif memiliki keunggulan dalam bidang intelektual, sosio-emosional, spiritual, fisik dan menolong peserta didik mengembangkan diri sesuai bakat atau minat mereka. Kedua, Kurikulum Holistik Integratif tidaklah terlalu berat untuk diterapkan, hanya saja dibutuhkan kesungguhan dari setiap tutor atau mentor untuk mengimplementasikan kurikulum ini dengan baik.

Ketiga, kurikulum Holistik Integratif tetap relevan diimplementasikan di PPA Cluster Medan-Pancur Batu dan bisa menjawab kebutuhan peserta didik yang ada di bawah naungan Yayasan Compassion ini. Keunggulan kurikulum Holistik ini dapat membentuk generasi yang berkarakter dan dapat memberi kontribusi bagi pembangunan manusia seutuhnya. Saran dari peneliti, bahwa ke depannya, para pengurus PPA, mentor dan tutor bisa bekerjasama dengan lebih baik lagi, dan membuat program pengembangan diri para tutor dan mentor sehigga implementasi Kurikulum Holistik ini bias lebih baik lagi.

\section{Referensi}

Abdiel E. Nawono. Buku Panduan Untuk Mentor Kurikulum Holistik Integratif. Bandung: Yayasan Compassion, 2015. 
Creswell, John W. Research Design: Pendekatan Metode Kualitatif, Kuantitatif dan Campuran. Yogyakarta: Pustaka Pelajar, 2019.

Dan Bwester. Anak, Gereja Dan Misi-Buku Panduan Pembimbing Kurikulum Holistik Integratif. Bandung: Compassion International, 2010.

MacCullough, Martha E. Mengembangkan Filosofi Pendidikan Berdasarkan Wawasan Dunia Kristiani (Malang: Gandum Mas, 2019), 156. Malang: Gandum Mas, 2019.

Oktaviani, Dewi Ayu, Dimyati. "Penerapan PAUD Holistik Integratif Pada Masa Pandemi Covid 19." Obsesi: Jurnal Pendidikan Anak USia Dini 3, no. 2 (2021).

Pramudyani, Avanti Vera Rusty. "Kurikulum Holistic Integrative Berbasis Permaiinan Tradisional Pada PAUD Di Yogyakarta." Jurnal Penelitian Ilmu Pendidikan 10, no. 2 (2017).

Sarinastitin, Elisabeth. "Pendidikan Holistik Integratif Dan Terpadu Untuk Pembentukan Karakter Anak Usia Dini." Unnes.ac.id 2, no. 2 (2019).

Tim Kurikulum. Compasion, Buku Panduan Pembimbing KurikulumHolistik Integratif. Bandung: Compassion Indonesia, 2010. 